\title{
THE FIRE SOURCE MODEL BASED ON THE IGNITED MATERIAL AND THE BURNING PROPERTY IN THE EARLY STAGE OF DWELLING-FIRES
}

\author{
佐藤博臣*, 水野智之** \\ Hiroomi SATOH and Tomoyuki MIZUNO
}

\begin{abstract}
To grasp a fire scenario in the case of the early stage of fire in the dwelling, a statistic analysis about the combination of " the ignited material - the ignition one " as the fire source was done using the fire report data, and some of " the ignited material - the ignition one " combinations having to do with a representative were extracted. Moreover, burning experiments about the fire source of the extracted combination were carried out and data about the basic burning property such as the heat release rate was grasped. From these results, a fire source model with five types was proposed as the early stage fire source at the dwelling.
\end{abstract}

Keywords : Ignited Material, Early Stage of Fire, Heat Release Rate

着火物、初期火災、発熱速度

\section{1 はじめに}

平成 14 年中の火元用途別火㷋被害状況(消防白書平成 15 年版)を 見るに、住宅火災件数は 19136 件で全建物火災の約 $56 \%$ を占めるに 至っている。住宅火災での死者数は 1233 人で約 $87 \%$ 、焼損床面積 は約 $50 \%$ 、損害額では約 625 億円、約 $46 \%$ を占めている。死者数に 関しては全建物火災の 9 割弱の割合で住宅火災において発生してお り、新聞報道においても連日高齢者や幼児の火災による死亡記事が 紙面をにぎわしている。住宅火災の多数の死者発生は、自殺放火あ るいは殺人放火等を別として、ハードな安全対策の不足、火炎覚知 の遅れ、逃げ遅れ、避難行動困難など火炎初期時の火災への人的対 态に問題の多くが内在している。確かに幼児や老人を多く抱えてい るという人的に不利な条件もさることながら、住宅という生活環境 としての物理的な装置やそこで営まれる生活行為そのもののなかに 危険性を内在しているものと考えられる。しかし住宅に最も安全な 環境を提供すべきなのか、それともさまざまな危険性が内在してい ることを認識してその対策を合理的な手法で解決す心゙きものである かについては社会的なコンセンサスが得られていない。他の建築用 途の多くで火災件数や死者数が減少しているにもかかわらず、住宅 火災で特に死者数が増加していることは、住宅火災に対して何らか の有効な方策の提言が強く望まれる状況にあると思われる。

一般に耐火設計や避難安全設計での火災シナリオは $\alpha \mathrm{t}^{2}$ モデル 火災を用いることが常套となってきているが、この $\alpha \mathrm{t}^{2}$ モデル火災 シナリオは、実火炎で通常存在する「発火一着火」の火炎初期のフ ェーズを工学的に無視している。しかし、火災覚知や初期消火にお
いてはこの火災発生時の火災シナリオが重要であるし、出火防止、 火災拡大 (内装制限)、避難・人命安全においても同様である。した がって、適切な提言のためには、住宅火災のこの「火災初期のフェ ーズ」に注目し工学的に把握する必要がある。

初期火災の火災シナリオモデルの確立をめざした研究開発 ${ }^{11}$ 、2)、 3)が、防火対象物の火災危険性に応じた合理的でかつ総合的な防火 安全対策手法の構筑の一環として行われつつある。また、住宅にお ける初期火災シナリオの研究として、火災荷重としての可燃物に関 する研究 $\left.\left.{ }^{4)}, 5\right) 、 6\right)$ や佐藤らの可燃物やその配置に関する研究 7)、8，99、 10)、11)、12) があるが、初期火炎時における出火源「着火物一発火源」 としての可然物に関する研究は少ない。

また、そのような火災発生時の火災シナリオのモデル提案、また、 その火災シナリオ提案モデルの検証のためには、実火災での初期火 源の実態やその燃焼性状をまず把握する必要がある。これらに関し ては、家具類の燃焼実験 ${ }^{13)}$ 、14) や収納可燃物の然焼実験 ${ }^{15)}$ はあるが、 まだ系統的な研究や燃焼性状に関する諸データが十分ではない。

そこで、住宅火災における火炎発生時の火災シナリオを把握する ために、火災報告データを用いて、出火源として「着火物一発火源」 の組合せの統計分析を行い、代表的な「着火物一発火源」の組合せ を抽出した。さらに抽出された組合せについて燃焼実験を行い、発 熱性状など基本的な燃焼性状に関わる諸データを把握した。これら の結果から、住宅における初期火源として 5 つのタイプの火源モデ ルを提案した。

\footnotetext{
*秼イー・アール・エス リスクマネジメント部 工修 Risk Management Dept. Engineering \& Risk Services Corporation, M. Eng.

** TOM 建築防災研究室 工博 TOM Building Fire Safety Labo., Dr. Eng.
} 
2 住宅火災における「着火物一発火源」

(1) 分析概要

発火源、着火物は出火個所（出火空間用途）に依存しているとと もに、建物用途区分や構造にも大きく依存しており、住宅用途の特 徽や他の用途との違いを明らかにするために、分析対象の建物用途 は防火対象物区分生 1 の 5 項口共同住宅等を含む（1）項イ〜（15） 項（事務所、官公庁）とした。また、たとえば発火源「たばこ」と 着火物「寝具類」、同様に「こんろ」と「動植物性油類」「「多一」と 「紙及び紙製品」、「電気機器」と「電線被覆」のように、特定の発 火源と着火物（可燃物）が強く関係していることから、着火物と発 火源の組合せを建物用途・空間用途区分別に分析抽出した。

分析は、消防の「火災報告」の平成 7 年度 10 年度の約 4 万 4 千 件のデータから、火元防火対象物区分、出火簀所、発火源および着 火物の 4 重ク口ス集計を行い、「防火対象物区分一出火篚所」別「着 火物一発火源」の組合せを原則として抽出した。

出火籄所の空間用途は、(1)主要空間用途 その建物用途の主要な 空間用途 (2)サービス・共用空間用途 廊下や階段、トイレといっ た空間 (3)火気使用空間用途 台所、調理場など火を使う空間 (4)屋外空間・その他空間 建物の外周部、壁軸組、屋根裏・天井裏 に大別した。

\section{（2）着火物と発火源}

表1は着火物を材質から分類したものである。下線は累計 $44 、 130$ 件における着火物の単純集計で、全体に 対する割合が $1 \%$ 以上を示している。因み に、単純集計の第1位は不明 (5394件、 $12.17 \%)$ 、続いて動植物油類 (4611件、 $10.41 \%) 、$ 紙・紙製品 (4016件、9.06\%) 布団・座布団・寝具 (3435件、7.45\%)、 紙首・わら屑 $(2805$ 件、6.33\%)、合成樹 脂及び製品 (2654件、5.99\%)の順となっ ている。多様な着火物となっているが、

「紙・紙製品」でも多種多様な可燃物が あるように、実際にはさらに着火物は多 様性を有している。

表2は発火源を、発熱が「火花のように 断続的なもの」と「灯火のように継続的 なもの」とに分け、さらに発熱の大きさ と炎の有無で分類区分したもので、着火 物と同様に発火源も多様なことを示して いる。下線は累計44、130件における発火 源の単純集計で、全体に対する割合が $1 \%$ 以上を示している。単純集計の第 1 位は不 明 $(10345$ 件、23.35\%)、たばこ(5501件、 $12.41 \%) 、 か ゙ ス こ ん ろ(5304$ 件、11.97\%)、 亏侈一 $(4685$ 件、10.57\%)、電熱器 (1433件、 $3.23 \%)$ 、電気機器 (1292件、 $2.92 \%)$ 、配 線 (1162件、2.62\%)、溶接機·溶断機 $(1152$

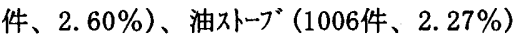
の順となっている。 (5)口奇宿舍·下宿·共同住宅
表 1 着火物の分類

\begin{tabular}{|c|c|}
\hline 着火物区分 & 抽出された着火物 \\
\hline \multirow{3}{*}{ 繊維類 } & (1)布団、座布団、寝具 \\
\hline & (2)衣類、緎維製品、緘維原料 \\
\hline & (3)わら及びわら製品、山林原野、乾燥草類 \\
\hline 紙類 & 紙・紙製品 \\
\hline \multirow{2}{*}{ 屑類 } & (1)ごみ屑、繊維屑、紙首、わら居、粉塺 \\
\hline & (2)木居、かんな屑、のこぎり屑 \\
\hline 木質類 & 木質物 \\
\hline $7^{\circ}$ ラスチック類 & 合成樹脂及び製品、合成樹脂屑、ゴム及びゴム製品 \\
\hline 油類 & 動植物性油類 \\
\hline \multirow{2}{*}{ 石油類 } & (1)第一、第二、第三、第四石油類 \\
\hline & (2)が 類 \\
\hline 電線類 & 電線被類 \\
\hline \multirow{3}{*}{ その他 } & (1)壁軸組、床 \\
\hline & (2)屋外の可燃物、可燃性固体、付帯建築物 \\
\hline & (3)断熱材、椅子・ソファー \\
\hline
\end{tabular}

\section{表 2 発火源の分類}

\begin{tabular}{|c|c|c|}
\hline 継続的な発熱(斜字；無炎) & & 断続的な発熱 \\
\hline たき火、風呂かまど、炬、焼却炬、ボイラー & \multirow{5}{*}{$\begin{array}{l}\text { 大 } \\
\uparrow \\
\text { 発 } \\
\text { 熱 } \\
\text { 鹿 } \\
\downarrow \\
\text { 小 }\end{array}$} & \\
\hline ガスこんろ等燃焼機器、油ストーブ & & 配線器具、配線、 \\
\hline 電気こんろ電気ストーブ，電熱器 & & 電気機器 $\cdot$ 装置 \\
\hline 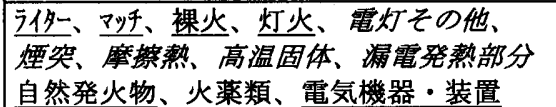 & & $\begin{array}{l}\text { 火花、炎の粉、 } \\
\text { 片ーク、溶接機 }\end{array}$ \\
\hline たばこ、取灰 & & \\
\hline
\end{tabular}

表 3 「5 項口 共同住宅等」における着火物一発火源

\begin{tabular}{|c|c|c|c|c|c|c|c|c|c|c|c|}
\hline 全体 & & & & 1 居衰 & & & & 2 台所 & & & \\
\hline 再灭物 & 発火源 & 件数 & 小此 & 童火物 & 発火源 & 件级 & 小叶 & 竞炎物 & 発炎源 & 吽数 & 小䀦 \\
\hline 称植物油 & $B \pi=h 3$ & 3098 & 3397 & 希団, 座S & たばこ & 1693 & 2517 & 别稙物油 & ガスこんろ & 2736 & 2978 \\
\hline 頑 & T㙰侽 & 110 & $18 \%$ & 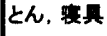 & 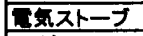 & 227 & $14 x$ & & 繁照 & 91 & \\
\hline & 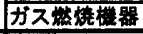 & 104 & & & ライター & 138 & & & 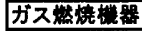 & 76 & \\
\hline 布団, 桽示 & たたばこ & 1829 & 2854 & & 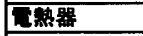 & 77 & & & 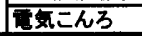 & 64 & \\
\hline <h, 䒠真 & 気자ーフ & 234 & $15 x$ & & 䙡火 & 63 & & 合成臌脂 & ガスこんる & 116 & \\
\hline & $519-$ & 173 & & & 油자-フ & 59 & & 及び笠品 & 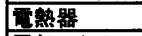 & 91 & \\
\hline & 不明 & 103 & & & 㞸明 & 52 & & & 雷汉こんろ & 26 & \\
\hline 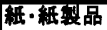 & 不明 & 698 & 1761 & 衣類 & ライター & 125 & 555 & ガス類 & ガスこんろ & 107 & 182 \\
\hline & 51タ- & 456 & $10 \%$ & & 油ストーブ & 82 & $3.0 \%$ & & 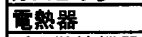 & 23 & 1.0 \\
\hline & たばこ & 186 & & & tたばこ & 79 & & & 历゙ス撚枿權器 & 16 & \\
\hline 媱崙, わら & たたばこ & 419 & 1260 & & 姡ストーブ & 72 & & 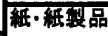 & カスこんろ & 26 & 9 \\
\hline 筒 & $518-$ & 375 & $6.8 \%$ & 維属, わら & $t=$ ばこ & 280 & 504 & & 熱器 & 17 & 0.51 \\
\hline & 不明 & 263 & & & ライター & 125 & $2.7 x$ & & ライター & 11 & \\
\hline 含成膰脂 & 不明 & 202 & 1230 & & マッチ & 28 & & 经共, わら & たぱこ & 43 & 9 \\
\hline 及び㓟品 & 等㽞 & 167 & $6.6 \%$ & 維·紙制品 & Бイター & 137 & 484 & 属 & 5イター & 13 & 0.50 \\
\hline & ライタ- & 144 & & & t=ばこ & 120 & $2.6 \%$ & & ガスこんろ & 11 & \\
\hline & カススんろ & 143 & & & 灯火 & 54 & & 衣頛 & ガスんんる & 48 & 8 \\
\hline & 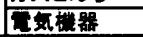 & 103 & & 扐植物油 & カスこんろ & 349 & 396 & & 熱举 & 6 & 0.479 \\
\hline 衣嫃 & 5イタ- & 212 & 900 & & 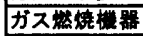 & 20 & $2.1 x$ & & $t=$ Kた & 6 & \\
\hline & 不明 & 121 & $4.9 \%$ & & T䓡帮 & 19 & & 司悘性固 & カススんろ & 57 & 6 \\
\hline & $t$ たばこ & 111 & & 㕅 & $t=$ だこ & 194 & 376 & & 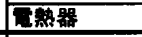 & 6 & $0.36 \%$ \\
\hline こみみ局 & たばこ & 315 & 660 & & 国楾 & 32 & $2.0 \%$ & 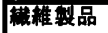 & ガスこんろ & 32 & 6 \\
\hline & 不明 & 154 & $3.6 \%$ & & R x자-フ & 22 & & & 繁噒 & 11 & 0.349 \\
\hline & 5イター & 81 & & 合成樹脂 & 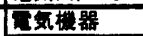 & 58 & 350 & & 曋乘にんろ & 4 & \\
\hline 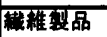 & $518-$ & 151 & 640 & 及び慗品 & 熱器 & 54 & $1.9 \%$ & & たば゚ & 4 & \\
\hline & 不明 & 107 & $3.5 x$ & & 酉線㗊县 & 54 & & Еみ㾍 & tたばこ & 42 & 62 \\
\hline & tシばこ & 102 & & & 奵火 & 51 & & & ガスこんろ & & 0.34 \\
\hline 第二石油 & 油자一フ & 180 & 479 & 第二石油 & 油ストーブ & 140 & 299 & & 不明 & 3 & \\
\hline & 5イター & 157 & $2.6 \%$ & |類 & 5イタ- & 102 & $1.6 \%$ & & 裸火 & 3 & \\
\hline & 不奛 & 50 & & & 不明 & 19 & & & קッチ & 3 & \\
\hline 床 & たばこ & 210 & 454 & 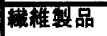 & tEぱこ & 81 & 290 & 第二石油 & 油자-フ & 30 & 5 \\
\hline & 圂線 & 33 & $2.5 x$ & & 5イター & 37 & $1.6 \%$ & & 5イタ- & 9 & 0.31 \\
\hline & 不明 & 29 & & & 油ストーブ & 31 & & & ガスこんろ & 5 & \\
\hline 全体 & & & 18502 & こみ屈 & $t=$ t゙こ & 138 & 211 & 台所合尌 & & & 461 \\
\hline & & & & & Бイター & 17 & $1.1 \%$ & & & & $24.9 \%$ \\
\hline & & & & & マッチ & 9 & & & & 以上 & \\
\hline & & & & 居室合計 & & & $\begin{array}{l}7993 \\
43.2 \%\end{array}$ & & & & 宫 $\%$ \\
\hline
\end{tabular}




\section{（3）「5 項口 共同住宅等」における着火物一発火源}

表 3 は、「5 項口 共同住宅等」における「着火物一発火源」の組 合せを抽出した結果の一部で、全体および出火件数の多い主要空間 用途として居室と火気使用室として台所を示している。全体では、 動植物性油類 (1 位)、布団・座布団・寝具 (2 位)、紙・紙製品 (3 位) の順となっている。居室部分では、不明を除いて着火物の上位 3 つ が布団・座布団・寝具 ( 1 位)、衣類 (2 位)、紙屑・わら屑 (3 位) であ り、その発火源はたばこ、ラ侈やや油外ーブ、電気外ーブとなっている。 発火源の単純集計でも、たばこ(2760 件)、ラ侈-(986 件)、がスこんろ (540 件)、油外 -ブ (453 件)、電気外-ブ (433 件)の順となっており、 たばこが原因の火災が約 35\%を占めている。台所では動植物性油類 が第 1 位の着火物となっており、その発火源はがスこんろが約 9 割と なっている。発火源の単純集計でも、がスこんろ(3442 件)、電熱器
（306）、たばこ(151 件)、電気こんろ(132 件)の順となっており、がス こんろからの火災が約 $75 \%$ を占めている。

住宅の居室では、出火源として発火源にたばこ、ラ㐴、、外ーブ、着 火物に衣類、紙眉・わら屑、紙・紙製品を、台所では発火源にこん ろ、着火物に動植物性油類と合成樹脂及び製品を想定すれば、それ ぞれ室用途全体の約 $50 \%$ 、約 70\%の火災を説明できることとなる。

\section{（4）「（1）項イ〜（15）項」における着火物一発火源}

住宅用途以外の用途の建物火災の着火物一発火源の関係を比較の ために以下に整理する。

表 4 は、各防火対象物区分の主要空閒用途における「着火物一発 火源」を整理して示したものであるが、原則として着火物の上位 3 位までの組合せを抽出している。出火箇所においては、ほとんどの

表 4 「(1) 項イ〜（15）項」における着火物-発火源

\begin{tabular}{|c|c|c|c|c|c|}
\hline 防火対象物区分 & 件数 & $\begin{array}{c}\text { 順位 空时用途 } \\
\text { 吽数 割合 }\end{array}$ & $\begin{array}{l}\text { 上位著火物 } \\
\text { 性数 }\end{array}$ & E火源 & \begin{tabular}{|l|} 
着火物 \\
抽出率
\end{tabular} \\
\hline (3)只飲食店 & $\begin{array}{r}2207 \\
4.8 \%\end{array}$ & $\begin{array}{l}2 \text { 飲食店舗部分 } \\
5622 \% \%\end{array}$ & 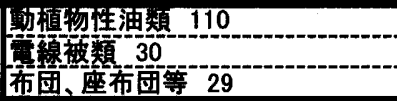 & 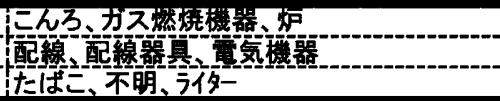 & \\
\hline & & $\begin{array}{l}1 \text { 調理室 } \\
70232 \%\end{array}$ & 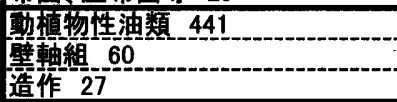 & 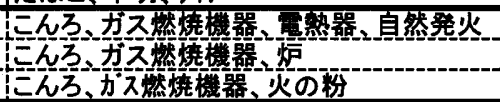 & 75 \\
\hline 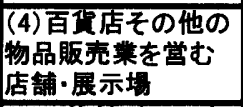 & $\begin{aligned} 1993 \\
4.3 \% \\
\end{aligned}$ & \begin{tabular}{|l}
1 物品販売店舗部 \\
分 $63131.7 \%$
\end{tabular} & 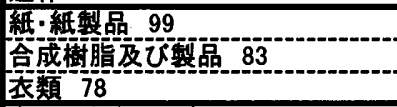 & 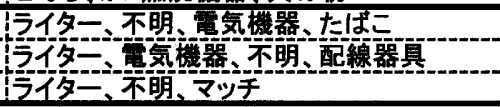 & 41 \\
\hline 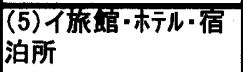 & $\begin{array}{l}725 \\
1.6 \%\end{array}$ & $\begin{array}{l}1 \text { 宿泊客室 } \\
177 \quad 24 \%\end{array}$ & 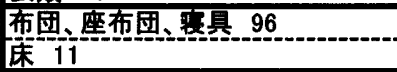 & 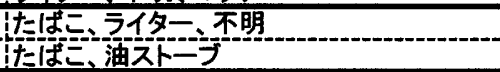 & 60 \\
\hline & & $\begin{array}{l}2 \text { 調理室 } \\
74 \quad 10 \%\end{array}$ & 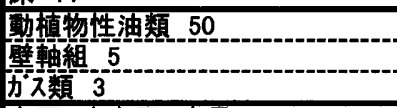 & 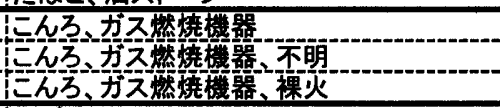 & 78 \\
\hline & & \begin{tabular}{|ll}
3 & 居室 \\
61 & $8.4 \%$ \\
\end{tabular} & 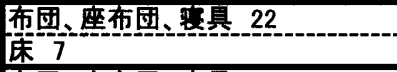 & 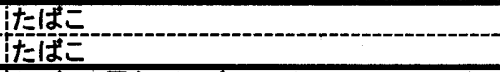 & 48 \\
\hline $\begin{array}{l}\text { (5)笪宿舎·下宿· } \\
\text { 共同住宅 }\end{array}$ & $\begin{array}{r}18502 \\
40.4 \%\end{array}$ & $\begin{array}{l}1 \text { 居室 } \\
7993\end{array} 43.2 \%$ & 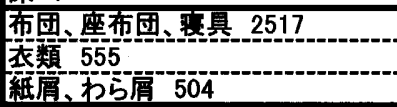 & 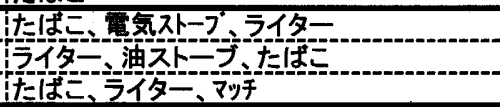 & 45 \\
\hline & & $\begin{array}{l}2 \text { 台所 } \\
4610 \quad 24.9 \%\end{array}$ & 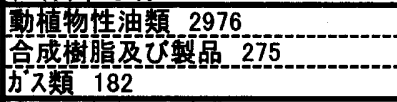 & 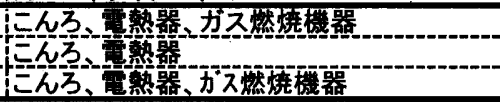 & \\
\hline 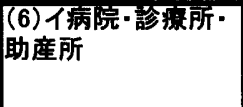 & $\begin{array}{l}551 \\
1.2 \%\end{array}$ & $\begin{array}{l}1 \text { 病室 } \\
14326 \%\end{array}$ & 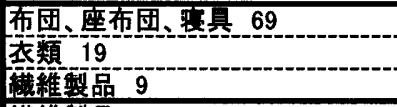 & 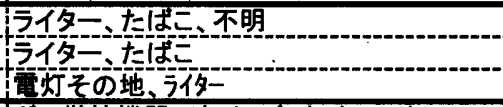 & 38 \\
\hline & & $\begin{array}{ll}5 & \text { 晾察室 } \\
25 & 4.5 \% \\
\end{array}$ & 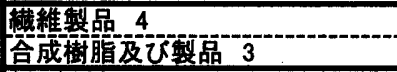 & 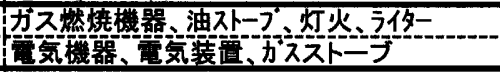 & 28 \\
\hline $\begin{array}{l}\text { (7)小学校·中学校· } \\
\text { 高等学校·大学等 }\end{array}$ & $\begin{array}{r}1717 \\
3.7 \%\end{array}$ & $\begin{array}{l}1 \text { 教室 } \\
305 \quad 18 \%\end{array}$ & 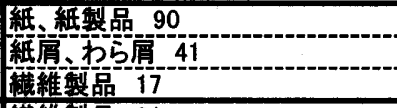 & 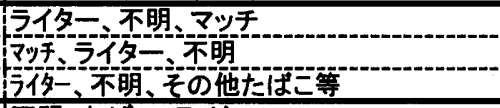 & 49 \\
\hline & & $\begin{array}{l}4 \text { 体育室(館) } \\
1398.1 \%\end{array}$ & 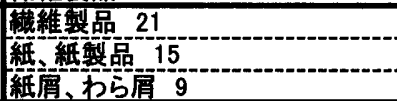 & 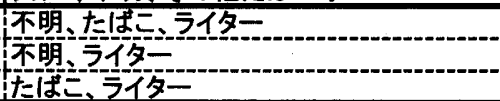 & \\
\hline & & 5 実験室、研究室 & 合成樹脂及ひ製品 18 & 箸愁器，電気機器，配線、配線器具 & \\
\hline & & $1378.0 \%$ & 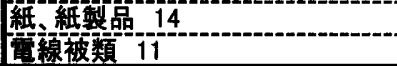 & 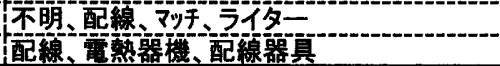 & \\
\hline (12)イ工場·作電所 & $\begin{array}{r}10241 \\
22.3 \%\end{array}$ & $\begin{array}{l}1 \text { 作宷所·工場 } \\
701867 \%\end{array}$ & 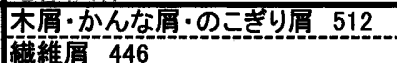 & 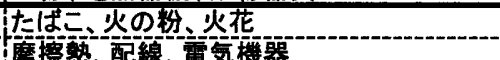 & \\
\hline & & & 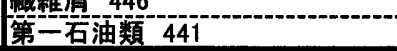 & 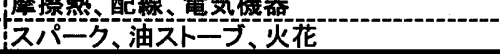 & 20 \\
\hline (14)倉庫 & $\begin{aligned} 3596 \\
7.8 \%\end{aligned}$ & $\begin{array}{l}1 \text { 一般倉庫 } \\
217861 \%\end{array}$ & 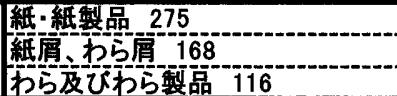 & 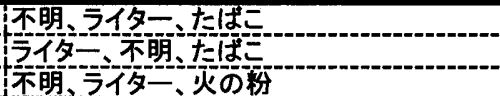 & 26 \\
\hline $\begin{array}{l}\text { (15)前各項に該当し } \\
\text { ない事莱所(事務 } \\
\text { 所) }\end{array}$ & $\begin{array}{r}1455 \\
3.17 \%\end{array}$ & $\begin{array}{ll}1 & \text { 一般事務室 } \\
408 & 28 \%\end{array}$ & 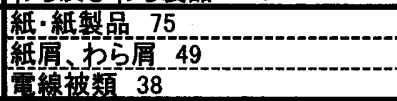 & 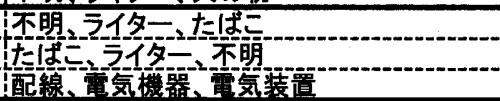 & \\
\hline
\end{tabular}


防火対象物区分で出火空間の第 1 位は主要用途空間となっており、 屋外空間である「外周部」が、ほとんどの防火対象物区分に共通し て上位抽出された。

抽出された着火物（以下、上位着火物という）をみれば、火気使 用空間では「動植物性油類」が、居室・就德空間では「布団・座布 団、寝具」が、それぞれ特定の用途区分での上位着火物となってい る。また、「紙・紙製品」、「合成樹脂及び製品」、「紙屑、わら屑小、

「壁軸組」、「電線被類」などは、ほとんどの用途区分で抽出されて おり、どの用途区分でも共通している上位着火物となっている。

上位着火物が「布団、座布団、寝具」となっているのは、共同住 宅の居室の他に旅館・ホテルの宿泊客室、病院の病室であり、「(1) 項口 公会堂・集会場」の「集会室・会議室」、「(3) 項イ 待合・料理 店その他これらに類するもの」の「飲食店舗部分」などでも座布団 が着火物になっていると考えられる。

表 4 の着火物の抽出率（各防火対象物区分・空間用途の全体数に 対する割合）をみると、火気使用室では、飲食店調理室が $75 \%$ 、旅 館・ホテル等の調理室が $78 \%$ 、共同住宅の台所が $74 \%$ 、の抽出率 で、上位着火物だけで約 7 割強となっており、各用途ごとにいくつ かの特定火災シナリオで説明できると推測できる。これに対して、 工場・作業所の作業所・工場では $20 \%$ 、倉庫の一般倉庫では $26 \%$ となっており、着火物・発火源の多様性を表している。

\section{3 初期火源一可燃物の燃焼性状}

\section{（1）可燃物の想定}

住宅における初期火源の燃焼性状を把握するために、統計分析の 結果から住宅における初期火源となる着火物 (可燃物)の種類を下記 のように想定し、これらの燃焼実験を行った。これらの可燃物がそ れぞれの種類を必ずしも代表するものではないが、できるだけ一般 的でかつ標準的な可燃物を想定した。

(1)「動植物性油類」天ぷら油

(2)「布団・座布団・寝具」布団セット

(3)「紙・紙製品」段ボーN箱、新聞紙

(4)「紙屑」「ごみ屑」 紙屑、ごみ箱(内容物)

(5)「合成樹脂及び製品」ごみ箱、空のビールケース

(6)「衣類」シや”

(1)「動植物性油類」〜6「衣類」の着火物で、住宅全体では $65 \%$ が、 居室では $63 \%$ 、台所では $78 \%$ の着火物が説明できる。実際には抽出 していない着火物も抽出した着火物と同様の燃焼性状を示すものも あるので、説明力はさらに上がると考えられる。

\section{（2）実験概要}

燃焼実験では、IS09705 に準拠したルームコーナー試験装置の集 煙フードの下あるいは燃焼室内で供試体を燃焼させ、下記の項目を 測定した。

(1)発熱速度 酸素濃度などの測定結果から酸素消費法を使って算出、 (2)供試体の重量減少 電子天秤で測定

(3)ビデオ記録、写真撮影

実験では、電子天秤の上に不然ボードをのせ、その上に薄い鉄板で 作った燃焼皿 (800 mm角) を載せて、その血の上に供試体を設置した。

各供試体の材質、量、形状、保持姿勢は下記のようにした。布団
セットやシャツなどは緎維の種類によってたばこやマッチ・ラ价ーでは着火 しても継続的な燃焼を呈しないものがあり、燃焼しやすい綿素材を 用いた。また、疊んだシや゙や新聞紙を除いて比較的に燃焼しやすい保 持姿勢とした。また、量や大きさは住宅における日常的な量を経験 的に設定した。

(1)天ぷら油

サラダ油 $750 \mathrm{~g}$ （比重 0.89）、鍋直径 $24 \mathrm{~cm}$

(2)布団セット

敷き布団と掛け布団（綿 $100 \%$ 中綿、綿 $100 \%$ 側地）約 $10 \mathrm{~kg}$

(3)段术一箱

段ボーN箱大 $1(503 \times 503 \times \mathrm{H} 503 \mathrm{~mm}$ 、段ボーN仕切入り、約 $3900 \mathrm{~g})$

段ボール箱大 2 （段ボール仕切、ポリスチレン製コップ入り、約 $7128 \mathrm{~g}$ ） 段ボーN箱小 $(400 \times 400 \times \mathrm{H} 360 \mathrm{~mm}$ 、約 $600 \mathrm{~g}$ : 段ボーN紙 厚さ $5 \mathrm{~mm}$ 、 $\left.470 \mathrm{~g} / \mathrm{m}^{2}\right)$ 、空箱や丸めた紙屑入り、仕切入り、折り畳みなど

\section{(4)新聞紙}

折り睤みひもでくくったもの、約 $7 \mathrm{~kg}$

(5)綎首

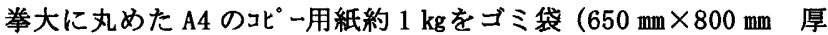
さ $0.02 \mathrm{~mm}$ ポリエチレン製）に入れた状態もの、同 $2 \mathrm{~kg} 2$ 袋、同新聞 紙約 $1 \mathrm{~kg}$ 等

(6)ごみ箱

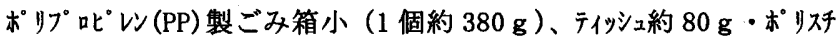
レントレ約 $25 \mathrm{~g} ・$ ポリ双レコップ 約 $35 \mathrm{~g}$ 入り

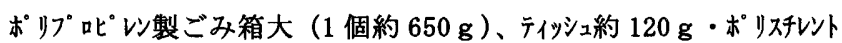
レ伱 $40 \mathrm{~g} ・$ ポリスチンコップ 約 $50 \mathrm{~g}$ 入り

(7) $\underline{E^{*}-\Lambda}$ -

ポリプロピレン(PP) 製ビールケース(空箱)、大瓶 20 本用 約 $2070 \mathrm{~g}$

2 種類メーカ一 $(x-カ-A$ およびメーカーB 各 2 ケース

(8)

綿 $100 \%$ のシャ゙(平均 1 着約 $300 \mathrm{~g}$ )、混紡(綿と化㵶(ポリエスデル)がほ ぼ半々のもの)のシャ゙（平均 1 着約 $180 \mathrm{~g}$ ） 5 着あるいは 10 着、 ハガーに吊りしたあるいは盼んで重ねた状態

\section{（3）点火源}

統計分析で抽出された着火物一発火源について、実験で完全な発 火状態の再現は困難であり、本研究の目的は、そのような条件下で の着火の可能性を探求することではないので、可能な限り統計分析 の結果を参考にして、表 5 のような各着火物に対して発火源を選定 し点火源とした。

表 5 实験供試体と点火源

\begin{tabular}{|c|c|}
\hline 実験供試体 & 実験の点火源 \\
\hline 天ぷら油 & ガスこんろ加熱による自然着火 \\
\hline 布団セット & $\begin{array}{l}\text { 火の著いたたばこ数本を政き布団 } \\
\text { と掛け布団の間に置く }\end{array}$ \\
\hline 段术一川箱 & ヘプ多燃焼火炎で下部底面から \\
\hline 段术一片箱 小 & 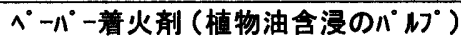 \\
\hline 紙屑・新閏紙 & 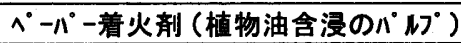 \\
\hline ごみ箱 (紙屑入り) & $\begin{array}{l}\text { 火の着いたたばこ } 4 \text { 本をデタシュで包 } \\
\text { みここみ箱内のごみの中に置く }\end{array}$ \\
\hline$t^{*}-\mu r-x$ & 固形燃料 (固形㶴/ $-N 、 30 \mathrm{~g})$ \\
\hline 衣類（吊下げ） & ラ㐴ーでつり下がった下部に着火 \\
\hline 衣類（曽置き） & ラ侈ーで下部に着火 \\
\hline
\end{tabular}




\section{（4）発熱速度}

天ぷら油 天ぷら油は、加熱後約 20 分で油に着火したが、その時の

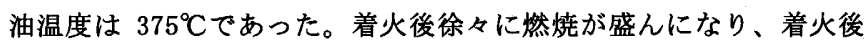
約 100 秒で最大発熱速度 $166 \mathrm{KW}$ を示した。（図 2 参照）

布団セット くん焼での発熱速度は、炭化範囲の狭いくん焼初期で は小さく測定範囲外であったが、炭化範囲が直径約 $50 \mathrm{~cm}$ 程度になっ た 60 分時点で約 $5 \mathrm{KW}$ 程度であった。 60 分経過後強制的に火をつけ 有炎燃焼の状態にした場合の発熱速度は最大約 $60 \mathrm{KW}$ であった。

段木゙ール箱 段ボール箱は、点火位置・方法によって燃焼の立ち上がり に違いが出ているが、段ボー箱小では中が空の場合に発熱速度が大 きく、燃焼盛期の発熱速度曲線の形は衣類に似て尖った山形となっ ている。紙屑を詰めたり段ボールで仕切りを入れたりすると空の場合 に比べて発熱速度が小さくなっている。また、折り畳んで立て掛け た場合、折り畳んだ段ボールを 2 倍の量にしても発熱速度は変わらな かった。この場合発熱速度は可燃物の空気に暴露している表面積に 依存しているためと考えられる。段ボーN箱大では、点火方法が違う ことと空の場合は行っていないため、小型と同様の比較ができない。 発熱曲線の形からは、小型の場合ほど仕切りの影響はなかったと思 われる。(図 1、図 3 参照)

新聞紙 新聞紙を轠んでひもでくくったものは、中発火源のラ侈等 に相当する小火炎では着火はするが継続的な燃焼をすることはなか った。

紙首 紙屑は、A4 切一用紙を拳大に丸めてゴミ袋に詰めたものを 供試体とした。紙を丸めてゴミ袋に詰めた状態は燃焼しやすい状態 であり、発熱速度の最大値はほぼ 60 秒前に出ており、燃焼盛期も 100 秒前に終わっている。(図 1、図 3 参照)

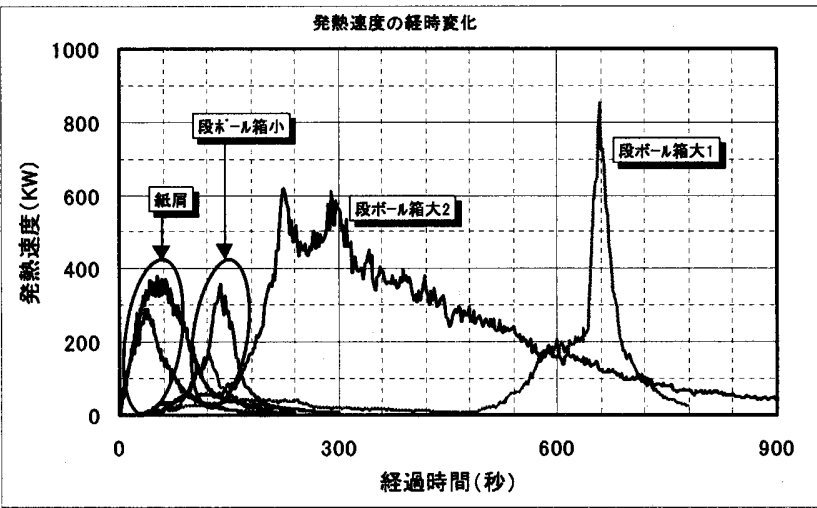

図 1 発熱速度 その 1

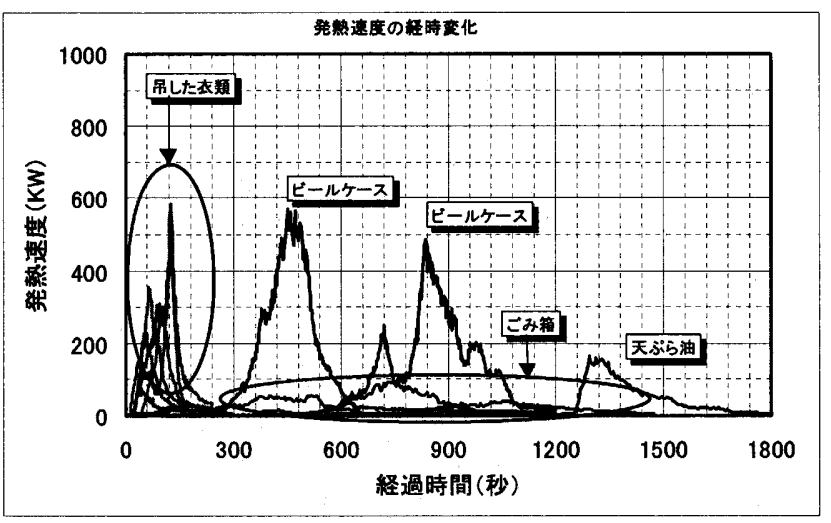

図 2 発熱速度 その 2
ごみ箱 ごみ箱は、たばこによる着火に時間がかかるためおよび発 熱速度も大半が $50 \mathrm{KW}$ 以下であるため、图 2 においてX軸に沿うよう に下方に細長く分布している。内容物のくず類の然焼は着火後 5 分 程度で終了するが、ごみ箱本体のポリプロピレッの燃焼が時間的には長 い。(図 2、図 4 参照)

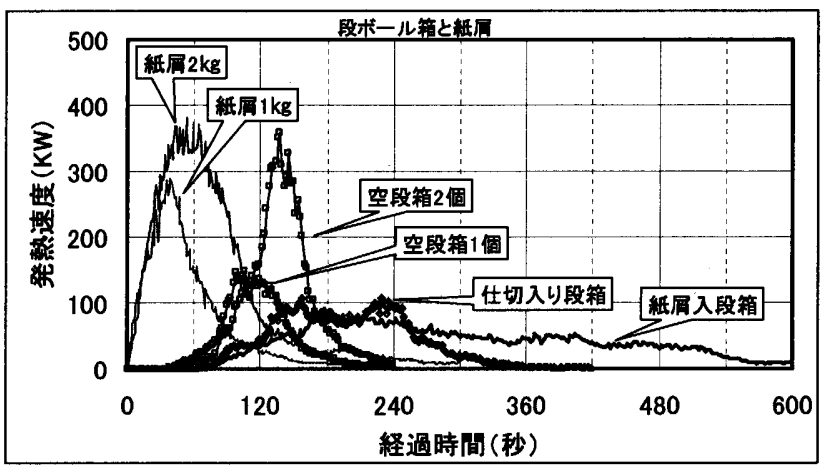

図 3 段末゙ $-ル$ 箱小と紙屑の発熱速度

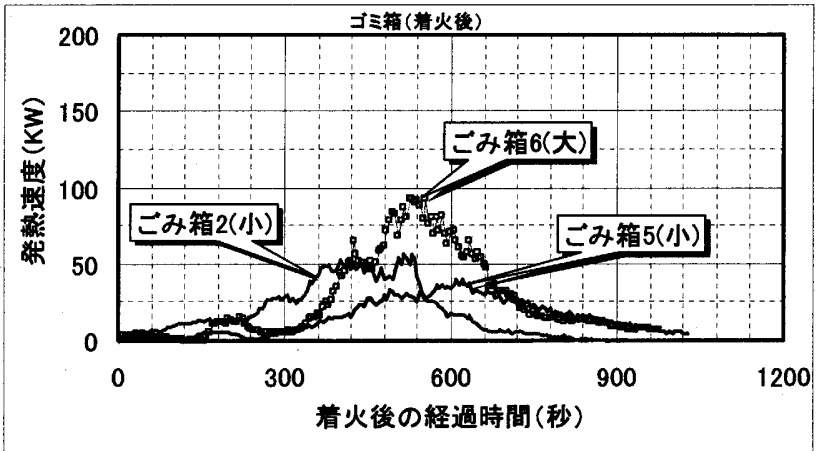

図 4 ごみ箱の発熱速度 (着火後)

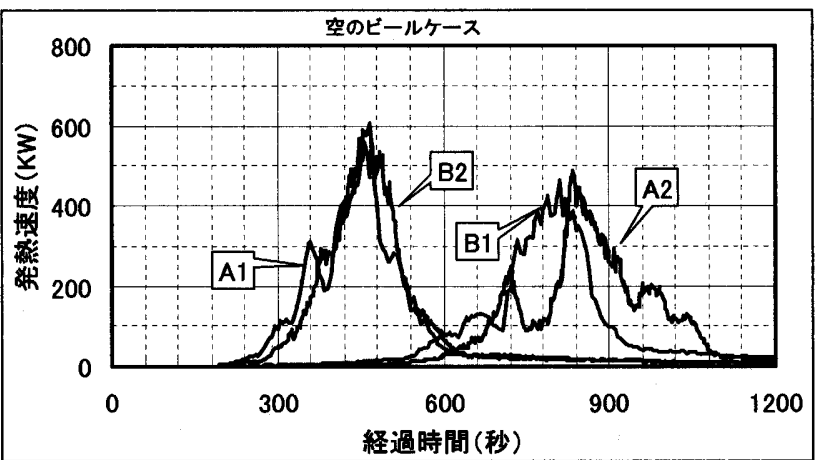

図 5 ビールケ-スの発熱速度

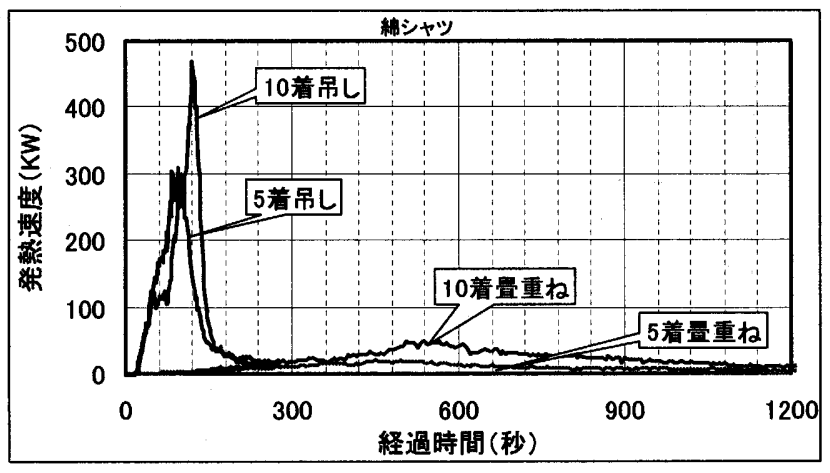

図 6 綿シャツの発熱速度 
ピーれケース PP 製ビールケースは、着火に固形然料を用いたが、着火に時間 がかかり燃焼ピークも早いケースで 7 分 8 分、遅いケースで 13 分 〜14 分もかかっている。ビ一昉一スは、火炎が当たると溶融し滴落し 然焼皿の上に溜まるが、燃焼部分から熱のフィードバックが十分あ れば、溜まったものが燃焼を維持・拡大しプール火災となる。今回の プール火災の大きさは燃焼皿の $80 \mathrm{~cm}$ 角に制限されており、最大の発熱 速度は $600 \mathrm{KW}$ であったが、ほぼ燃焼血全面で然焼している状況での 值である。（図 2、図 5 参照）

衣類 吊した綿シャ゙はラ侈で簡単に着火する。その燃焼は、今回の結 果では、継続時間は短く 3 分程度となっており、図 2 の左下隅の○

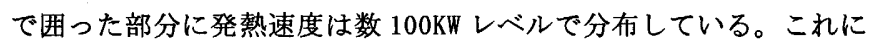
対して、畳んで置いた状態では、着火後の然焼は緩やかで、 5 着ず つ 2 山に積んだケースでも最大の発熱速度が $50 \mathrm{KW} 、$ 燃焼盛期の平均
の発熱速度は約 30KW であつた。(図 2、図 6 参照)

割合がほぼ半々のポリエステルと綿の混紡シがッ、綿シがと同様に中発火 源のラ侈で着火し燃焼する。

\section{4 初期火源の燃焼モデル化}

時間一発熱速度のグラフ上に可然物の最大発熱速度とその最大值 を示した時刻をプロットしたものが、図 7 である。くん焼燃焼の布

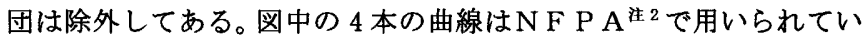
る $\alpha \mathrm{t}^{2}$ モデル火災である。紙を丸めた紙屑や吊した衣類の燃焼拡大 (火災成長：最大值までの増加)は速く ultrafast や fastに相当してい る。これに対してプラスチック製ごみ箱やビールケースは小火炎による着 火では全体に火炎が拡大する(燃焼がピークになる)までに時間がか かっている。

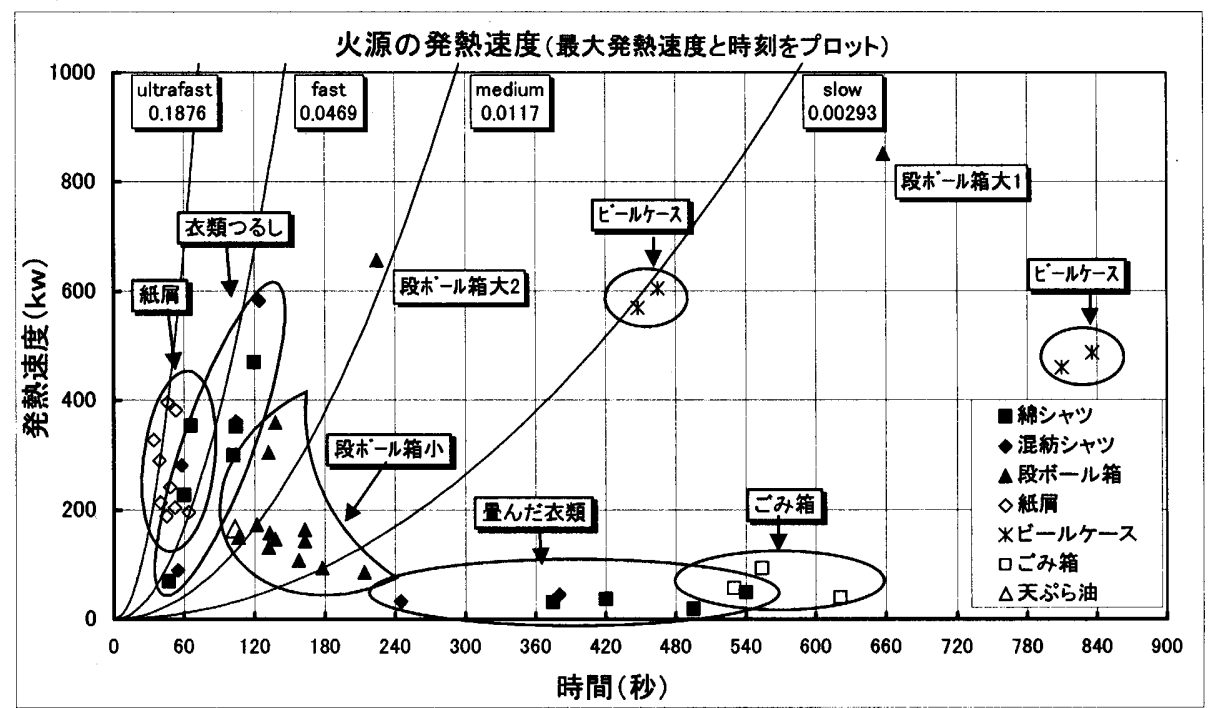

図 7 火源の発熱速度 (最大発熱速度とその時刻)
発熱速度 (最大值、平均值)、火災成長 係数 $\alpha$ 值、燃焼盛期継続時間、単位発熱 量(燃焼熱 $\mathrm{KJ} / \mathrm{g}$ )の結果を、各可燃物の種 類毎に数值を丸めて表 6 に整理した。発 熱速度の平均值は燃焼盛期 (最大発熱量 の $1 / 2$ 以上の発熱速度のある期間)での 平均発熱速度 $(\mathrm{KW})$ である。火災成長係数 は最大発熱速度とその時刻から計算した。 燃焼継続時間は平均発熱速度で総熱量 (重量 $\times$ 単位発熱量)を割った值である。 単位発熱量は各時刻の発熱量 $(\mathrm{KJ})$ と燃焼 量 $(\mathrm{g})$ をプロットしたグラフからその曲 線を直線近似しその傾きとして求めた。

ごみ箱では発熱速度は約 $50 \mathrm{KW}$ で燃焼 継続時間は約 8 分となっている。 比一用 紙 $1 \mathrm{~kg}$ を丸め紙屑では発熱速度は約

表 6 発熱速度測定の結果一筧

\begin{tabular}{|c|c|c|c|c|c|c|c|c|}
\hline \multirow{2}{*}{ 可燃物 } & & \multirow{2}{*}{ 保持姿勢 } & \multirow{2}{*}{$\begin{array}{c}\text { 重量 } \\
\mathrm{g}\end{array}$} & \multicolumn{2}{|c|}{ 発熱速度 $(\mathrm{KW})$} & \multirow{2}{*}{$\begin{array}{l}\text { 火災成長 } \\
\text { 係数 }(\alpha)\end{array}$} & \multirow{2}{*}{$\begin{array}{c}\text { 燃焼経続 } \\
\text { 時間(s) }\end{array}$} & \multirow{2}{*}{$\frac{\text { 燃焼熱 }}{(\mathrm{KJ} / \mathrm{g})}$} \\
\hline & & & & 最大値 & 平均値 & & & \\
\hline 天ぷら油 鍋直径24cm & & ガスこんろ加熱 & 750 & 170 & 120 & $1.6 \mathrm{E}-02$ & 300 & - \\
\hline 布団セット & & 有炎燃焼 & - & 60 & - & - & - & - \\
\hline 段木゙ール箱大 $503 \times 503 \times 503$ & 1箱 & 仕切入り & 3,900 & 850 & 600 & 2. $7 \mathrm{E}-02$ & 111 & 17 \\
\hline \multirow{2}{*}{ 段ボール箱小 $400 \times 400 \times 360$} & 1箱 & 組立中空 & 620 & 160 & 120 & 1. $2 \mathrm{E}-02$ & 88 & 17 \\
\hline & 2箱 & 組立中空重ねおき & 1,300 & 330 & 250 & 1. $8 \mathrm{E}-02$ & 80 & 16 \\
\hline 段术一几箱小 $400 \times 770 \times 20$ 厚 & 1箱 & 折りたたみ、立てかけ & 610 & 140 & 100 & $8.2 \mathrm{E}-03$ & 98 & 16 \\
\hline 段术一ル箱小 $400 \times 770 \times 40 / \frac{1}{4}$ & 2箱 & 折りたたみ、立てかけ & 1,200 & 150 & 110 & $5.8 \mathrm{E}-03$ & 157 & 14 \\
\hline \multirow{2}{*}{ 紙首 A4 比一用紙 } & $1 \mathrm{~kg}$ & 丸めてゴミ袋に詰める & 1,000 & 280 & 200 & 2. $0 \mathrm{E}-01$ & 65 & 13 \\
\hline & $2 \mathrm{~kg}$ & 丸めてゴミ袋に詰める & 2,000 & 390 & 300 & 1. $6 \mathrm{E}-01$ & 100 & 15 \\
\hline \multirow{2}{*}{ ごみ箱(PP) } & 小 & & 520 & 50 & 35 & 1. $5 \mathrm{E}-04$ & 480 & 42 \\
\hline & 大 & & 860 & 90 & 55 & 3. $0 \mathrm{E}-04$ & 480 & 42 \\
\hline$t \leftarrow-ル ケ-\lambda(P P)$ & 1個 & 空のケース & 2,100 & 530 & 380 & 7. $3 \mathrm{E}-03$ & 234 & 43 \\
\hline \multirow{4}{*}{ 綿シャツ } & 10着 & 畳み重ねおき & 3,100 & 35 & 25 & 2. $1 \mathrm{E}-04$ & 1742 & 14 \\
\hline & 1着 & 吊し & 340 & 70 & 55 & 3. $2 \mathrm{E}-02$ & 90 & 14 \\
\hline & 5着 & 吊し & 1,300 & 290 & 210 & $5.8 \mathrm{E}-02$ & 90 & 15 \\
\hline & 10着 & 㐖 & 2,200 & 410 & 280 & 3. $3 \mathrm{E}-02$ & 120 & 15 \\
\hline \multirow{2}{*}{ 混紡シャツ } & 10着 & 畳み重ねおき & 1,800 & 40 & 30 & 4. $3 \mathrm{E}-04$ & 1200 & 20 \\
\hline & 10着 & 吊し & 1,700 & 580 & 430 & 3. $8 \mathrm{E}-02$ & 70 & 18 \\
\hline
\end{tabular}

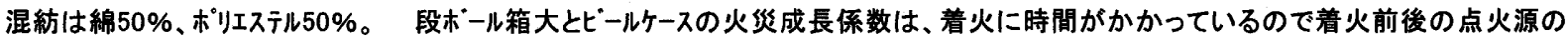
燃焼が主流の部分を除外して求めた。 
$280 \mathrm{KW}$ で燃焼継続時間は約 65 秒、燃焼熱は約 $13 \mathrm{KJ} / \mathrm{g}$ となっている。

吊した綿ジ゙ (10 着)では、最大発熱速度は約 $410 \mathrm{KW} 、$ 平均発熱速度 は約 $280 \mathrm{KW}$ で然焼継続時間は 120 秒となる。これに対して混紡シが(10 着)では最大発熱速度は約 $580 \mathrm{KW}$ 、平均発熱速度は約 $430 \mathrm{KW}$ と綿シヤ゙ に比べて大きな值となっている。段ボール箱は大小 2 種類行っている が、大型の段ボール箱で最大発熱速度は $850 \mathrm{KW}$ 、平均発熱速度は $600 \mathrm{KW}$

\section{表 7 各可撚物のパラメータ值}

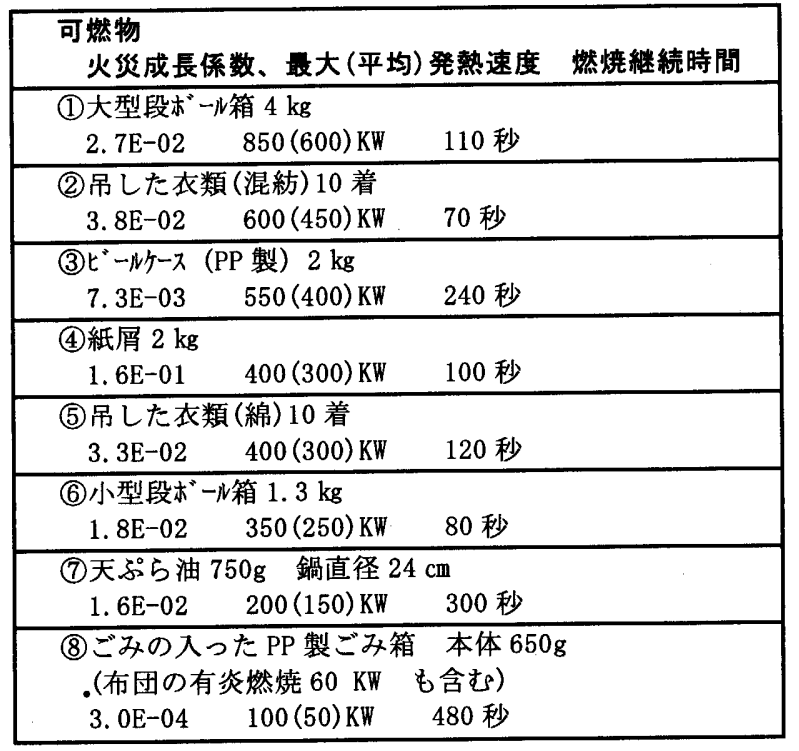

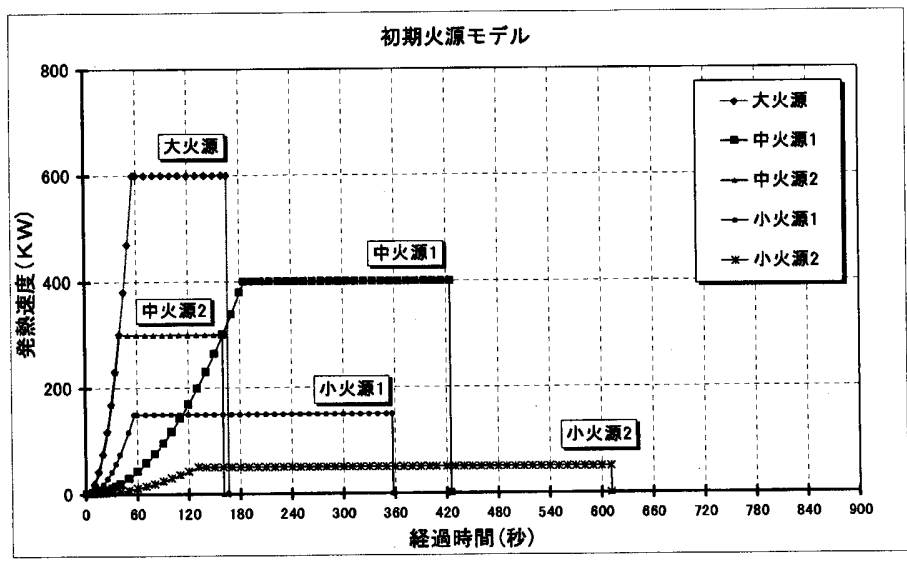

图 8 初期火源モデルの発熱速度

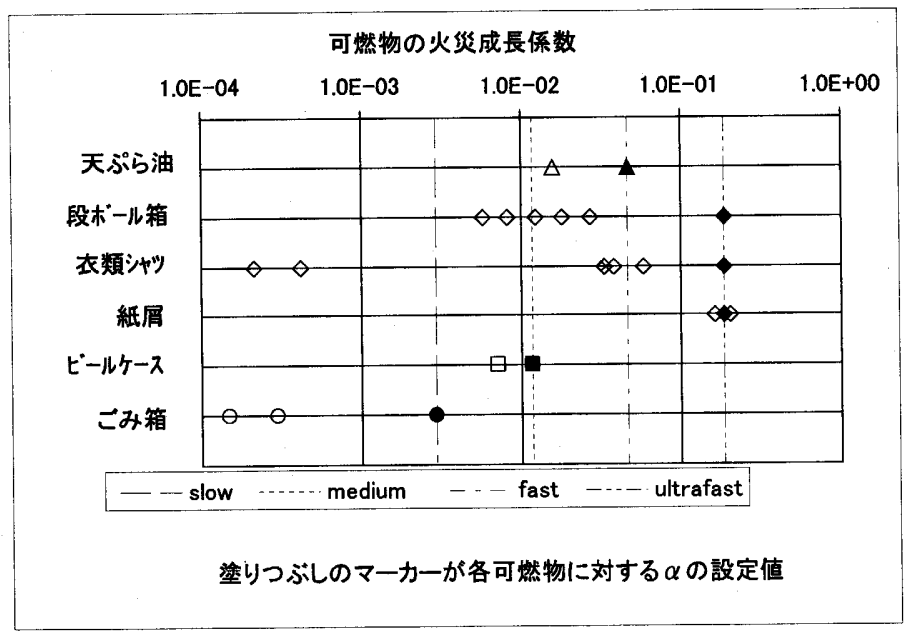

図 9 初期火源モデルの火災成長係数
で然焼継続時間は 111 秒となっている。

衣類の場合は、吊した状態より畳んだ状態の方が、着火した火炎 の全体一の拡大が遅く発熱速度も小さい。段ボール箱も同様に、組み 立てた空箱の状態より中に紙屑を詰めたり、折り畳んだ状態の方が 発熱速度は小さくなっている。このように保持姿勢によって発熱速 度に大きな差が出ている。

\section{5 住宅の初期火源モテルの提案}

表 6 の結果から、表 7 の(1)〜8のように各可燃物に対して、火災 成長倸数、最大発熱速度 (あるいは平均発熱速度) と燃焼継続時間の 3つのパラメータを用いた整理を行った。

初期火源の燃焼特性は、同じ材質の火源においても、形状・大き さや量、保持姿勢等により違いがある。しかし、量や大きさ、保持 姿勢に関しては実態データなども少なく、実態調査を行ってそれら を設定す心゙きであるが、今回はとりあえず、可然物の種類に関して は、本報の表 3を参考にして表 7 の１8のように設定し、量に関 しては住宅における日常的な量として、実験結果を参考にしながら 経験的に設定している。したがって、今後実態調査等を行って設定 数值等の妥当性を検討する必要があるが、例えば量についてもし実 際には設定した量の 2 倍の可燃物があるのであれば、初期可燃物が 2 つ隣り合わせて存在していると考えて、燃焼拡大を考虑して発熱 速度あるいは燃焼継続時間の数值を割り增しして用いるなどすれば 実用的には満足できる。

上記(1)〜 (8)の初期可燃物とその燃焼特性をもとに、火炎成長保 数、平均発熱速度と燃焼継続時間の 3 つのパラメータを用いて、 図 8 及び表 8 に示すような、住宅の初期火源を代表する火源とし て 5 タイプの初期火源モデルを提案できる。

火源モデルの型としては、「発熱速度が平均発熱速度に達する までは $\alpha \mathrm{t}^{2}$ で発熱速度は増加し、平均発熱速度に達した時刻以降 は平均発熱速度で一定、燃焼継続時間だけ一定の発熱速度を保ち 燃焼は終了する。」ものを考えた。各可然物の $\alpha$ 值としては、N F PAの ultrafast、fast、medium と slow の 4 つ值を採用した。 この火源モデルが他の着火物(2 次着火物)一の着火を考えるため のものであり、可燃物の発熱速度を忠実に表現する必要はないの で、図 9 に示すように、表 6 および表 7 の值を基に、各可燃物の $\alpha$ の設定值が安全側となるように ultrafast(UF)、fast(F)、 medium(M)、slow(S)のいずれかの值を設定した。

大火源は(1)と(2)の可燃物をもとにしており、火炎成長係数は ultrafast としている。可燃物のイメージとしては、紙類や衣類で、 可燃物量としては多量な值(紙類では数 $\mathrm{kg}$ 、衣類では十数着程度の 量)としている。中火源 1 は(3)をもとにしており、大火源に比べて 火炎成長係数が小さく mediumで、燃焼継続時間が長い。可燃物 イメージとしては、PP やPE のプラスチック等で可燃物量として は多量 (数 $\mathrm{kg}$ ) としている。中火源 2 は(4)〜(6)をもとにしており、 火災成長係数が大火源と同様に ultrafast となっている。可燃物 イメージは大火源と同様で、可然物量は少量 (多量の半分以下) と している。小火源はともにゆっくりとした燃焼で燃焼継続時間も 長く、小火源 1 は(7)の天ぷら火災をもとにしており、火災成長係 数が fast となっている。小火源 2 は(8)をもとにしており、布団の 有炎燃焼も表現している。火災成長係数はslowとなっている。 
表 8 初期火源モデル

\begin{tabular}{|c|c|c|c|c|}
\hline \multirow[b]{2}{*}{ タイプ } & \multicolumn{3}{|c|}{ パラメータ } & \multirow[b]{2}{*}{ 可燃物イメージ } \\
\hline & $\begin{array}{l}\text { 火災成長係 } \\
\text { 数 }\end{array}$ & $\begin{array}{l}\text { 平均発 } \\
\text { 熱速度 }\end{array}$ & $\begin{array}{l}\text { 継続時 } \\
\text { 間 }\end{array}$ & \\
\hline 大火源 & 1. $88 \mathrm{E}-01 \mathrm{UF}$ & $600 \mathrm{KW}$ & 110 秒 & 紙、衣類 多量 \\
\hline 中火源 1 & 1. $17 \mathrm{E}-02 \mathrm{M}$ & $400 \mathrm{KW}$ & 240 秒 & プラスチック 多量 \\
\hline 中火源 2 & $1.88 \mathrm{E}-01$ UF & $300 \mathrm{KW}$ & 120 秒 & 紙、衣類 少量 \\
\hline 小火源 1 & 4. $69 \mathrm{E}-02 \mathrm{~F}$ & $150 \mathrm{KW}$ & 300 秒 & 天ぷら油 \\
\hline 小火源 2 & 2. $93 \mathrm{E}-03 \mathrm{~S}$ & $50 \mathrm{KW}$ & 480 秒 & プラスチック \\
\hline
\end{tabular}

住宅の各室毎の可燃物配置に対応して、これらの初期火源を適宜 設定すれば、発生する初期火災性状を空間用途毎により的確に表現 することができる。統計分析で抽出されていないその他の火源にお いても、その多くはその然焼性状が 5 つの火源タイプのどれかに包 含されるものと考えられるから、この 5 つの初期火源モデルで、住 宅の初期火源の多くは説明できる。さらに、居室や台所といった室 空間用途別に、「着火物一発火源」の統計分析の結果をもとに重み付 けされた初期火源モデルの設定も可能である。

\section{6 おわりに}

火災統計データを用いて、建物用途・空間用途毎の「着火物一発 火源」の分析を行い、標準的な着火物において燃焼実験を実施し、 その燃焼性状のデータを得て、住宅の初期火源モデルを提案した。

ここで取り上げた代表的な可燃物は、多種多様な可然物の 1 例に 過ぎず、その量や保持姿勢が変われば然焼性状も異なる。しかし、 マク口的な見地でみれば、紙屑や衣類、段ボーN箱などここで取り上 げた可燃物の燃焼性状をもとに標準火源モデルの大まかなプロト夕 イブを提案することができる。また、これら統計分析の結果と然焼 データから、火災初期における初期火源のモデルを空間用途毎に設 定することも可能である。

謝辞 この論文の一部分である統計分析と燃焼実験は、消防総プロ 「総合防火安全対策手法の開発調査」の一環として実施したもので、 実施に当たっては出火桩大防止防炎幹事会の各幹事に貴重なご意見 を頂いた。とくに実験に関して主查の消研箭内氏には大変ご助力頂 いた。ここに深謝いたします。

注 1 防火対象物区分

消令別表第 1 で、下記のように(1) 項から (20) 項まで分類されている。本論 では (1) 項から (15) 項までを対象とした。

(1) 項イ 制場、映画館など

(1) 項口 公会堂又隹会城

(2)項イ キャバレー、カフェーなど

（2）項口遊技場またはダンスホール

(3) 項イ 待合、料理店など

(3) 項口 飲食店

(4) 項帛货店、マーケットなど店舗または展示場

(5) 項イ 旅館、ホテルなど

(5) 項口 寄宿舎、下宿又は共同住宅

(6) 項イ 病院、診療所など

(6) 項口 老人福祉施設、有料老人ホームなど

(6) 項八 幼稚園、盲学校など

(7) 項 小学校、中学校なと

(8) 項図畫館、博物館など

(9) 項イ 蒸気浴場、熱気浴場など

(9)項口イに揭げる公衆浴場以外の公衆浴埸

(10)項 車両の停車場または船舶若しくは航空機の発着場

(11) 項 神社、寺院など

（12）項イ 工場又は作業場

(12)項口 映画スタジオ又はテレビスタジオ

（13）項イ 自動車車庫又は駐車場
(13) 項口 飛行機又は回転翼航空機の格納庫

(14) 項 倉庫

(15) 項 前各項に該当しない事業場

(16)項イ 複合用途防火奶象物のうち、その一部が(1)項から (4) 項まで、(5) 項イ、(6) 項又は (9)イに揭げる防火対象物の用途に供されているもの (16)项口1に揭げる複合用途対象物以外の褯合防火対象物

(16 の 2) 項 地下街

(16の3)愐 篧地下街

(17)項 文化財

(18) 項 延長 50 メートル以上のアータード

(19)項 市町村長の指定する山林

(20)項 自治省令で定める舟車

注 2 N F P A

NFPA72、NFPA92B では、火災感知器の分析あるいは煙制御システムのデザ インの目的て、、ultrafast(UF)、fast(F)、medium(M)、slow(S)の 4 つに等級 化された $\alpha \mathrm{t}^{2}$ 火災を火源モデルに用いている。各火災モデルの $\alpha$ 值は、 $\alpha \mathrm{t}^{2}$ 曲線で発熱速度が增加するとし、発熱速度が $1055 \mathrm{KW}(1000 \mathrm{BTU} / \mathrm{sec})$ となる時 間(火災成長時間)をそれぞれ 75、150、300、600 秒として求められたものて ある。様々な可燃物の発熱速度のデータが公表されているが、ほとんどの可燃 物の $\alpha$ 值は $0.001 \sim 1$ のオーダーの間に入ると言われており、それらが参考と なっている。NFPA の 4 つの $\alpha \mathrm{t}^{2}$ 火災は以下のような代表的な可然物と関連づ けられている。

Slow Densely packed paper products(高密度に固められた紙製品)

Midium Traditional mattress/boxspring(伝統的なマットレス/ボックススプリング) Cotton/polyester interspring mattresst(綿/ポエステN マットレス)

Fast PU mattress(horizonta1) (ウレタソクオームマットレス) Wood pallets $5 \mathrm{ft}$ high(5フィート積みの木製ペ・ット)

Ultrafast Thin plywood wardrobe(板厚の薄い合板張り洋服犳)

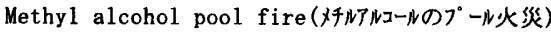
Fastest burning upholstererd furniture(最大燃焼速度の詰め物家具)

\section{参考文献}

1）関沢愛、ほか 3 名:消防用設備等の防火設計における総合的防火性能評価 のフレームワーク 一消防用設備を中心とした総合的防火性能評価法の開 発 その 1、日本建築学会大会学術講演梗概集、A2、pp. 187,188, 2002.08 2）海老原学、ほか 2 名:火災時の避難行動支援対策の評価法 一消防用設備 を中心とした総合的防火性能評価法の開発 その 2、日本建築学会大会学 術講演梗概集、A2、pp.189,190,2002.08

3）野竹宏彰、ほか 4 名:火災時の初期桩大抑制対策の評価法 一消防用設備 を中心とした総合的防火性能評価法の開発 その 3、日本建筑学会大会学 術講演概集、A2、pp.191,192, 2002.08

4)(財)第一住宅協会、(財)日本住宅・木材技術センター、住宅の積载荷重に関 寸る調查、1982.03

5）(財) 日本建築センター、新都市躯体構造システム報告書 IV 可燃物調查、 1988

6）日本住宅公団、高㳟住宅の防火総合計画に関する研究、1974.06

7）佐藤博臣、ほか 4 名:木造住宅の火災荷重に関する分析、その 1 積载火 災荷重について、日本建築学会大会学術講演梗概集、A2、pp.31,32、1997.09

8）阿部京子、佐藤博臣、ほか 3 名、住宅における木質系可燃物の配置に関す る研究、その 1 住宅の家具配固に関する分析、日本建築学会大会学術講 演梗概集、A2、pp.183,184、1998.09

9）関沢愛、佐藤博臣、ほか 5 名:住宅における木謪系可燃物の配置に関する 研究、その 2 R C 造中層住宅における木質系可燃物の配圈の実態、日本 建築学会大会学術講演梗概集、A2、pp.185, 186、1998.09

10）佐藤博臣、ほか 2 名:住宅における木質系可然物の配圈に関する研究 そ の 2 住宅の家具配圈に関する分析(その 2)、日本建築学会大会学術講演梗 概集、A2、pp.109,110、1999.09

11）佐藤博臣、ほか 3 名:住宅における可然物配圆のモデルに関する研究、日 本建築学会大会学術講演梗概集、A2、pp.177,178、2001.09

12）岩波志富贵、佐藤博臣:住居内可燃物とバルコニー利用状況との関係につ いて、日本建築学会関東支部研究報告集、I、2002.03

13）昭和 53 年度総プロ「住宅性能絰合評価システムの開発」報告書、安全 に関する評価法および測定法の開発(防火安全性能の評価方法の開発、資料 編)、建築研究所、1978

14）川越邦雄、水野智之:閉空閒における家具類の燃焼性状 その 2、日本建 築学会大会講演梗概集、防火、pp.2807,2708、1983

15）吉田正志:収納可燃物の燃焼性状その $1 \sim 3$ 、日本建築学会大会学術講演 梗概集、A2、pp.37,38、2000.09、pp.1,2、2001.09、pp.265,266、2002.08 16）水野智之、佐藤博臣:建物・空間用途別にみた火災初期における初期火源 およびその燃焼性状、日本建築学会大会学術講演梗概集、A2、pp.207〜210、 2002.08 